\title{
Non-specific effects of passive immunization on implantation in the rabbit*
}

\author{
B. M. Bhatt and D. W. Bullock \\ Department of Cell Biology, Baylor College of Medicine, Houston, Texas 77030, U.S.A.
}

\begin{abstract}
Summary. Passive immunization with goat anti-rabbit uteroglobin antiserum prevents implantation in the rabbit. The dose of antiserum was too low to neutralize all of the uteroglobin present on Day 5 of pregnancy, however, and the effect could not be shown to be specific, because 'control' treatments with goat antiserum to chick avidin or normal goat serum also prevented implantation. Non-specific antisera raised in rabbits had little or no effect on implantation. Partial purification of antibodies from the non-specific goat antisera reversed their effect, while anti-uteroglobin gamma globulin still reduced implantation. Fluorescein-labelled gamma globulin fractions of anti-avidin and anti-uteroglobin both bound to blastocysts, but pure FITC-IgG showed binding only of anti-uteroglobin. Both anti-avidin and antiuteroglobin IgG prevented implantation. It is concluded that the effect on implantation is not necessarily achieved via a specific antigen.
\end{abstract}

\section{Introduction}

Passive immunization is a technique which has been used in studies of implantation, on the assumption that inhibition of implantation by a specific antibody would indicate a necessary function of the corresponding antigen. For example, Rosenfeld \& Joshi (1977) found that intraluminal passive immunization with an antiserum against a uterine peptidase prevented implantation in the rat, and concluded that these results indicated "a role for this enzyme in implantation". Two reports have described prevention of pregnancy in the rabbit by passive immunization with antisera against uteroglobin. Krishnan (1971) showed inhibition of implantation in 5 out of 8 animals and suggested that "blastokinin [i.e. uteroglobin] plays a major role ... in the normal development of rabbit embryos". Johnson (1974) was more conservative in the interpretation of his results, which showed that implantation was not affected by intraluminal injection of antiserum to uteroglobin on Day 6.5 of pregnancy but that subsequent fetal wastage was greatly increased.

Despite the passage of 10 years since its discovery (Beier, 1968a; Krishnan \& Daniel, 1967), the biological role of uteroglobin remains obscure. We have re-investigated the possible function of uteroglobin in implantation by using passive immunization with a variety of antisera.

\section{Materials and Methods}

\section{Antisera}

An antiserum raised in goat to chick avidin (Cappel Laboratories, Cochranville, Pennsylvania) and an antiserum raised in rabbit to goat immunoglobulin (Antibodies Inc., Davis, California) were purchased. Antiserum raised in rabbit to chick avidin was a gift from Dr Pamela Sperry (Department of Cell Biology, Baylor College of Medicine). An antiserum to rabbit uteroglobin, prepared from uterine flushings of pregnant animals by preparative polyacrylamide gel electrophoresis, was obtained by injecting a goat with $3,3,1.5$ and 1.5 mg uteroglobin in Freund's complete adjuvant at 0,6 ,

\footnotetext{
* Reprint requests (with stamped and adressed envelope, except outside the U.S.) to Dr D. W. Bullock.
} 
12 and 30 weeks respectively. The goat was exsanguinated 3 weeks after the last injection; the antiserum was absorbed with rabbit serum albumin cross-linked with glutaraldehyde (Avrameas \& Ternynck, 1969) and tested for specificity by immunoelectrophoresis against uterine proteins from pregnant rabbits.

Gamma globulin fractions of anti-uteroglobin and goat anti-avidin antisera were prepared by precipitation with $\left(\mathrm{NH}_{4}\right)_{2} \mathrm{SO}_{4}$ as described by Campbell, Garvey, Cremer \& Sussdorf (1964). These fractions were labelled with fluorescein isothiocyanate (FITC: Isomer 1, Sigma) by the procedure of Kawamura (1977). The reaction mixture was applied to a column of Sephadex G-25, previously equilibrated with $5 \mathrm{~mm}$-sodium phosphate buffer, $\mathrm{pH} 8 \cdot 1$, and the FITC-labelled protein was eluted with the same buffer. Pure FITC-labelled IgG was isolated from the eluate by ion-exchange chromatography on a column of DEAE-cellulose (Whatman DE 52). The column was washed with 5 volumes of $5 \mathrm{mM}$-sodium phosphate buffer, $\mathrm{pH} 8 \cdot 1$, and 3 protein peaks were eluted with stepwise gradients of $0.05 \mathrm{M}$-sodium phosphate buffer, $\mathrm{pH} 6.3,0.1 \mathrm{M}$-sodium phosphate buffer, $\mathrm{pH} 6.3$, and $1.0 \mathrm{M}-\mathrm{NaCl}$. The material eluting with the $0.05 \mathrm{M}$-sodium phosphate buffer, $\mathrm{pH} 6.3$, was pure FITClabelled IgG and its fluorescein to protein ratio was calculated from the formula of Hudson \& Hay (1976), i.e. $2.87 \times$ absorbance at $495 \mathrm{~nm} /[$ absorbance at $280 \mathrm{~nm}-(0.035 \times$ absorbance at $495 \mathrm{~nm})$ ]. The purified IgG fractions had low FITC : protein ratios of 1.7 for anti-uteroglobin and 1.5 for antiavidin. Pure IgG without FITC was isolated from the gamma globulin fractions by DEAE-cellulose chromatography in a similar manner.

\section{Animals and experiments}

Adult, virgin female New Zealand white rabbits were tested for lordosis by manual stimulation and were mated twice to fertile bucks. Immediately after mating, the females were injected intravenously with 75 i.u. hCG to ensure ovulation (Day 0 of pregnancy). The animals were anaesthetized with sodium pentobarbitone (Nembutal) and the uteri were exposed. Various serum samples, either whole or diluted with $0.154 \mathrm{M}-\mathrm{NaCl}$ solution, in a total volume of $100 \mu \mathrm{l}$, were injected into the lumen of each uterine horn. Some horns were not injected and served to indicate the normal incidence of implantation.

Experiment 1. On Day 5 of pregnancy, a single injection of 0.01 to $0.1 \mathrm{ml}$ of whole antiserum, raised in goat or rabbit, against uteroglobin, chick avidin or goat IgG, or of normal goat serum was given to opposite uterine horns, as summarized in Table 1. Laparotomy was performed on Day 9 and the numbers of implantation sites and corpora lutea were counted. Using the same experimental design, the study was repeated with gamma globulin fractions of goat antiserum to rabbit uteroglobin, goat antiserum to chick avidin and normal goat serum. In other rabbits, the experiment was repeated with purified $\mathrm{IgG}$ fractions of goat antiserum to uteroglobin and goat antiserum to avidin.

Experiment 2. In some rabbits, a $0.01-\mathrm{ml}$ equivalent of FITC-labelled gamma globulin from the goat antisera to uteroglobin and avidin was injected into opposite uterine horns (one antiserum in each horn) on Day 6 of pregnancy. After $6 \mathrm{~h}$, the blastocysts were flushed out with $0 \cdot 154 \mathrm{M}-\mathrm{NaCl}$ solution, washed and examined by fluorescence microscopy.

Experiment 3. Blastocysts were recovered on Day 6 and incubated ( $3 /$ flask) for $1 \mathrm{~h}$ at $37^{\circ} \mathrm{C}$ in $5 \%$ $\mathrm{CO}_{2}$ in air in $1 \mathrm{ml}$ medium TC 199. Four flasks each contained one of the following treatments: $50 \mu \mathrm{g}$ anti-uteroglobin-FITC-IgG alone, $50 \mu \mathrm{g}$ anti-avidin-FITC-IgG alone or each of these two fractions plus $1 \mathrm{mg}$ of the respective IgG fractions not labelled with FITC.

\section{Results}

The effects on implantation of passive immunization with the various antisera (Exp. 1) are summarized in Table 1. Injection of goat antiserum against uteroglobin significantly reduced the number of implantations, but goat anti-avidin antiserum also prevented implantation. Rabbit anti-IgG antiserum had no effect on implantation and rabbit anti-avidin antiserum showed none or little suppression compared to goat anti-avidin. Normal goat serum prevented implantation in a dose-related manner. 


\section{PLATE 1}
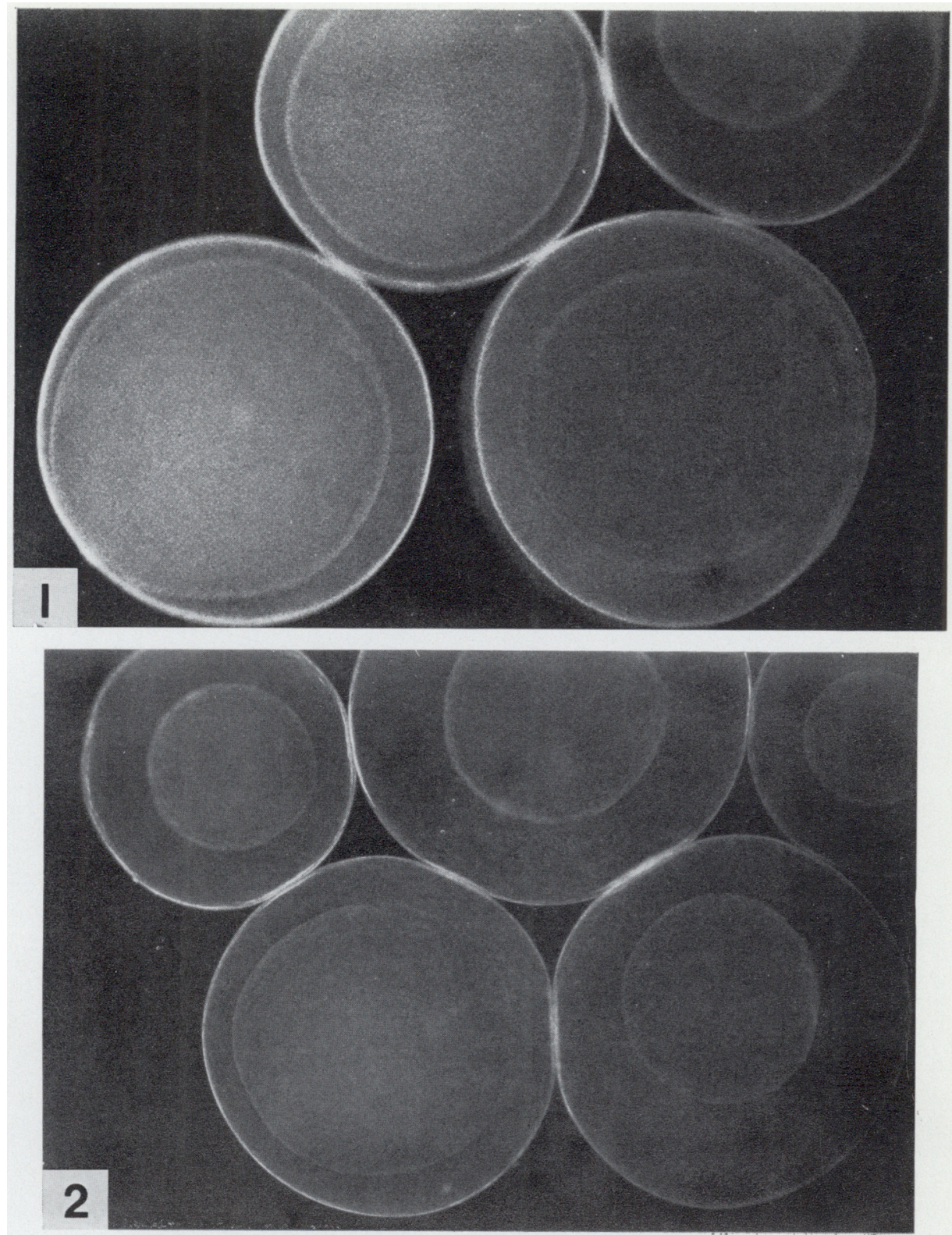

Figs 1 and 2. Fluorescence of 6-day rabbit blastocysts recovered from uterine horns $6 \mathrm{~h}$ after intraluminal injection of FITC-labelled anti-uteroglobin gamma globulin (Fig. 1) or anti-avidin gamma globulin (Fig. 2). 
Table 1. Effects of intraluminal passive immunization with various antisera on implantation in the rabbit

\begin{tabular}{|c|c|c|c|c|}
\hline \multirow[b]{2}{*}{ Treatment } & \multirow{2}{*}{$\begin{array}{c}\text { Dose of } \\
\text { antiserum* } \\
\text { (ml) }\end{array}$} & \multicolumn{3}{|c|}{ No. of implantations/no. of corpora lutea } \\
\hline & & Whole serum $(\%)$ & Gamma globulint $(\%)$ & $\operatorname{IgG} \ddagger(\%)$ \\
\hline \multirow[t]{3}{*}{ Goat anti-uteroglobin } & $0 \cdot 1$ & $12 / 41(29)$ & $17 / 41(41)$ & - \\
\hline & 0.05 & $9 / 38(24)$ & $26 / 36(64)$ & - \\
\hline & 0.01 & $8 / 19(42)$ & $15 / 31(48)$ & $12 / 23(52)$ \\
\hline \multirow[t]{2}{*}{ Goat anti-avidin } & $0 \cdot 1$ & $0 / 21(0)$ & $7 / 13(54)$ & - \\
\hline & 0.01 & $2 / 15(13)$ & $8 / 8(100)$ & $0 / 14(0)$ \\
\hline \multirow[t]{3}{*}{ Normal goat serum } & $0 \cdot 1$ & $6 / 26(23)$ & $8 / 13(62)$ & - \\
\hline & 0.05 & $5 / 13(39)$ & $8 / 9(89)$ & - \\
\hline & 0.01 & $10 / 10(100)$ & $8 / 8(100)$ & - \\
\hline \multirow[t]{2}{*}{ Rabbit anti-avidin } & $0 \cdot 1$ & $8 / 9 \quad(89)$ & - & - \\
\hline & 0.05 & $9 / 17(53)$ & - & -- \\
\hline \multirow[t]{2}{*}{ Rabbit anti-goat IgG } & $0 \cdot 1$ & $12 / 16(75)$ & - & - \\
\hline & 0.05 & $5 / 7 \quad(71)$ & - & - \\
\hline None & - & $58 / 73(79)$ & - & - \\
\hline
\end{tabular}

\footnotetext{
* All doses given in total volume of $0.1 \mathrm{ml}$.

$\dagger\left(\mathrm{NH}_{4}\right)_{2} \mathrm{SO}_{4}$ fraction; protein equivalent to dose of whole serum.

$\$$ DEAE-cellulose purified; protein equivalent to dose of whole serum.
}

The results with the gamma globulin fractions (Table 1) showed that the effects of goat anti-avidin and normal goat serum were substantially reversed. The effects of goat anti-uteroglobin were lessened, but there was still significant depression of implantation. When pure IgG fractions of these antisera were injected, however, both anti-uteroglobin and anti-avidin interfered with implantation.

Fluorescent antibodies were bound to the zona pellucida and outer trophoblast of all the blastocysts, regardless of the antiserum instilled (Pl. 1, Figs 1 and 2). Discounting the possibility that the rabbit blastocyst contains avidin, the binding of anti-avidin antibodies could only be non-specific because the anti-avidin antiserum showed no cross-reaction with uteroglobin or uterine flushings during immunoelectrophoresis.

Purified FITC-labelled IgG fractions (Exp. 3) showed binding of anti-uteroglobin, which was partly displaced by excess anti-uteroglobin IgG (not labelled), but no binding of anti-avidin IgG whether or not excess non-labelled IgG was present.

\section{Discussion}

Although goat antiserum against uteroglobin impaired implantation, the specificity of this effect was dubious because goat anti-avidin antiserum or normal goat serum also reduced implantation. Non-specific antisera raised in rabbits had little or no effect, so that it seemed likely that the species of origin of the antiserum was more important than the antibodies it contained. Partial purification of gamma globulin fractions generally reversed the effects of the non-specific goat sera, while goat anti-uteroglobin gamma globulin still reduced implantation. The lack of a clear dose-response relationship in some cases is difficult to explain; possibly the effect varies with the proximity of the blastocysts to the site of injection at the time of treatment.

The small amounts of antiserum injected ( $2-20 \mu \mathrm{g}$ antibody protein) could not have neutralized all of the uteroglobin present in the lumen on Day 5 ; we calculate that to do so would require about 700 mg pure antibody. The antibodies could therefore have prevented implantation by binding to uteroglobin contained in the blastocyst (Beier, 1968b; Hamana \& Hafez, 1970; Kirchner, 1976). The binding of FITC-labelled anti-uteroglobin gamma globulin supports this hypothesis. However, because anti-avidin gamma globulin also bound to the blastocyst, pure FITC-IgG fractions were prepared in an attempt to investigate specificity of binding by competition with non-labelled IgG. 
In fact, anti-avidin FITC-IgG showed no binding to the blastocyst either alone or in the presence of competitor. We interpret this finding to indicate that the binding of anti-avidin gamma globulin was non-specific; it may have been due to a higher FITC : protein ratio in the gamma globulin fraction compared to the pure IgG, causing binding by charge effects of the FITC label rather than by proteinprotein interaction.

Some specificity of binding of anti-uteroglobin IgG was indicated by the partial displacement with excess non-labelled IgG. Thus it was of interest to determine whether the binding of the pure IgG fractions was correlated with their effects on implantation. The results (Table 1) showed that this was not so, and anti-uteroglobin IgG and anti-avidin IgG both prevented implantation. We have no explanation for this result, unless alterations in the permeability of the blastocyst coverings can be invoked (Kulangara, 1975).

While anti-uteroglobin antibodies prevent implantation, they cannot be shown to do so specifically either in vivo or by binding to blastocysts in vivo or in vitro with any degree of certainty. Binding of proteins to blastocysts in vitro has been reported by Hakansson \& Sundqvist (1976), who found binding of ${ }^{125} \mathrm{I}$-labelled human serum albumin, human transferrin and normal rabbit IgG to mouse blastocysts. In some cases, the binding could be displaced by the corresponding non-radioactive protein. While these results were not directly correlated with implantation, Reimers, Sluss \& Seidel (1978) have briefly reported that antibodies raised against the immunizing adjuvant can prevent pregnancy in mice.

It is therefore clear that because implantation is suppressed by a passively administered specific antiserum, one cannot necessarily conclude that the effect is brought about by abolition of the corresponding specific antigen. Our results lend no support to the necessity for uteroglobin in implantation in the rabbit; they indicate that results from passive immunization experiments must be interpreted with a great deal of caution.

We thank Mr Karl Ebert and Dr Bernard Pollara, of Albany Medical College, for help with preparation of the antiserum. The work was supported in part by funds from a Ford Foundation grant to Dr D. P. Swartz, Albany Medical College, from NIH grant HD 09378 and from Rockefeller Foundation grant 76001. Dr Mary Bordelon helped with the fluorescence microscopy.

\section{References}

Avrameas, S. \& Ternynck, T. (1969) The cross-linking of proteins with glutaraldehyde and its use for the preparation of immunoabsorbents. Immunochemistry 6, 53-66.

BEIER, H.M. (1968a) Biochemisch-entwicklungsphysiologische Untersuchungen am Proteinmilieu fur die Blastocystenentwicklung des Kaninchens (Oryctolagus cuniculus). Zool. Jahrb. Anat. 85, 72-190.

BEIER, H.M. (1968b) Uteroglobin: a hormone-sensitive endometrial protein involved in blastocyst development. Biochim. biophys. Acta 160, 289-291.

Camprell, D.H., Garvey, J.S., Cremer, N.E. \& Sussdorf, D.H. (1964) Methods in Immunology, pp. 118-120. W. A. Benjamin, Inc., New York.

Hakansson, S. \& Sundevist, K.G. (1976) Binding of proteins to mouse blastocysts after the attachment stage of implantation. Upsala J. med. Sci. 81, 139144.

Hamana, K. \& Hafez, E.S.E. (1970) Disc electrophoretic patterns of uteroglobin and serum proteins in rabbit blastocoelic fluid. J. Reprod. Fert. 21, 555558.

Hudson, L. \& HAY, F.C. (1967) Practical Immunology, p. 12. Blackwell Scientific Publications, Oxford.
Johnson, M.H. (1974) Studies using antibodies to the macromolecular secretions of the early pregnant uterus. In Immunology in Obstetrics and Gynecology, pp. 123-133. Eds A. Centaro \& N. Caretti. Int. Congr. Ser. No. 327, Excerpta Med. Found., Amsterdam.

Kawamura, A. (1977) Fluorescent Antibody Techniques and their Applications, 2nd edn, pp. 45-55. University of Tokyo Press, Tokyo.

Kirchner, C. (1976) Uteroglobin in the rabbit. 1 Intracellular localization in the oviduct, uterus, and preimplantation blastocyst. Cell Tiss. Res. 170, 415424.

KrISHNAN, R.S. (1971) Fffects of passive administration of antiblastokinin on blastocyst development and maintenance of pregnancy in rabbits. Experientia 27, 955-956.

KRIShNAN, R.S. \& Daniel, J.C., JR (1967) "Blastokinin": inducer and regulator of blastocyst development in the rabbit uterus. Science, N. Y. 158, 490-492.

Kulangara, A.C. (1975) Absence of maternal proteins in 5-7 day blastocyst fluid indicates limited protein passage before implantation. J. exp. Zool. 193, 101-108. 
Reimers, T.J., Sluuss, P.M. \& Seidel, G.E., JR (1978) Control agents for antisera disrupt pregnancy in mice. Proc. 10th Ann. Meeting Soc. Study Reprod., Austin, Abstr. 121.
RoseNFeld, M.G. \& Joshn, M.S. (1977) A possible role of a specific uterine fluid peptidase in implantation in the rat. J. Reprod. Fert. 51, 137-139.

Received 24 Februng 1978 